\title{
Endogenous Timing in a Mixed Oligopoly with Foreign Competitors: the Linear Demand Case
}

\author{
Yuanzhu Lu \\ Received September 4, 2005; revised version received January 9, 2006 \\ Published online: April 18, 2006 \\ (C) Springer-Verlag 2006
}

We introduce foreign private firms into the model of Pal (1998) and investigate the impact of the introduction of foreign private firms on the endogenous timing in a mixed oligopoly in the linear demand case. We find that the public firm chooses to be a follower of all domestic private firms and that the public firm chooses not to be a leader of all foreign private firms, which is in contrast to Matsumura (2003).

Keywords: mixed oligopoly, endogenous timing, foreign competitors.

JEL Classification: L13, D43, H42.

\section{Introduction}

Studies of mixed markets, in which welfare-maximizing public firms compete against profit-maximizing private firms, have become increasingly popular in recent years. ${ }^{1}$ The mixed oligopoly consists of public firms and domestic private firms in most of the literature on mixed oligopoly, but foreign private firms are also included in a few studies. For example, Corneo and Jeanne (1994) considered mixed oligopolies in an international setting where public firms compete with domestic private

1 See De Fraja and Delbono (1990), and Nett (1993) for general reviews of the mixed oligopoly models. For recent literature on mixed oligopoly (duopoly), see Matsushima and Matsumura (2003a), Matsushima and Matsumura (2003b), Bárcena-Ruiz and Garzón (2003), Fjell and Heywood (2004), Matsumura and Kanda (2005), and Lu and Poddar (2005), etc. 
firms and foreign private firms, characterized the equilibrium and explored welfare implications of nationalization, privatization and the creation of a public firm. Fjell and Pal (1996) investigated the effect of the introduction of foreign private firms on the equilibrium price and allocation of production (relative to the case when all private firms are domestically owned); Fjell and Heywood (2002) considered a mixed oligopoly in which a public Stackelberg leader competes with both domestic and foreign private firms.

In the literature on mixed oligopoly, most of the articles assume firms make quantity choices simultaneously or sequentially and the order of moves is treated as exogenously given. There also have been some papers discussing endogenous timing in a mixed oligopoly since an alternate order of moves often produces significantly different results and thus leads to different welfare level. For example, Pal (1998) analyzed endogenous order of moves in quantity choice in a mixed oligopoly consisting of a single public firm and $n$ domestic private firms. ${ }^{2}$ Matsumura (2003) considered endogenous roles of firms in a mixed duopoly market where a state-owned public firm and a foreign private firm compete.

However, there is no paper discussing endogenous timing in a mixed oligopoly with both domestic and foreign private firms. There are no foreign private firms in Pal (1998) and no domestic private firms in Matsumura (2003). In reality, public firms, domestic private firms and foreign private firms coexist in many industries and in many countries. The electricity industry in some european countries such as Germany and France is a good example after the deregulation of electricity in the European Union. ${ }^{3}$ So the endogenous timing in such a mixed oligopoly is very important and it is surprising that there is no paper discussing such a question. The purpose of this paper is to fill in this gap and to address the issue of endogenous timing in a mixed oligopoly consisting of a public firm, domestic and foreign private firms, in particular, to investigate the impact of the introduction of foreign private firms on the endogenous timing in a mixed oligopoly.

Hamilton and Slutsky (1990) is a seminal work in the endogenous timing literature. In this paper, the authors considered two different extended games in the context of a quantity setting duopoly: one is the extended game with observable delay and the other is the extended game with action commit-

2 Jacques (2004) slightly corrects proposition 4.1 of Pal (1998).

3 See the introduction section of Matsushima and Matsumura (2005) for more examples. 
ment. In this paper, we consider the extended game with observable delay in the context of a quantity setting mixed oligopoly where firms first announce in which period they will choose their quantities and are committed to this choice before they actually choose their quantities and the mixed oligopoly consists of one public firm, $n(\geq 1)$ domestic private firms and $m(\geq 1)$ foreign private firms. At this stage, we focus on the linear demand case. We find that in any equilibrium, the public firm chooses to be a follower of all domestic private firms, the public firm chooses not to be a leader of all foreign private firms, which is in contrast to Matsumura (2003), and that the number of subgame perfect Nash equilibria (SPNE) depends on the number of the domestic private firms and that of the foreign private firms.

The organization of the paper is as follows. In Sect. 2, we describe the model. Section 3 presents the results when there are only three possible periods for quantity choice. The SPNEs are presented in Sect. 4 when there are more than three possible periods to be chosen. Section 5 concludes the paper.

\section{The Model}

Consider a mixed oligopoly model with one public firm, $n(\geq 1)$ domestic private firms and $m(\geq 1)$ foreign private firms, all producing a single homogenous product. Let $q_{0}, q_{i}^{d}$ and $q_{j}^{f}$ be the quantities of the public firm, of domestic private firm $i$ and of foreign private firm $j$, respectively. Let $Q=q_{0}+\sum_{i=1}^{n} q_{i}^{d}+\sum_{j=1}^{m} q_{j}^{f}$ denote the aggregate quantity. The market price is determined by the inverse demand function $p=a-Q$. Assume that $a$ is sufficiently large. All domestic and foreign private firms have constant and identical marginal costs of production, which are normalized to $0 .^{4}$

The public firm also has constant marginal cost of production. To make the results in this paper directly comparable to those of Pal (1998), the public firm is assumed to be less efficient than the private firms. ${ }^{5}$ Let

4 We do not consider the efficiency differential between the domestic private firms and the foreign private firms for the sake of simplification. See the concluding section for discussion.

5 This assumption also allows us to avoid a trivial solution. If the public firm is more efficient than the private firms or equally efficient, it would produce a quantity such that the market price equals its marginal cost, resulting in a public monopoly. 
$c>0$ be the marginal cost of the public firm. For the sake of simplification, fixed costs are assumed to be zero for all firms.

We consider the observable delay game of Hamilton and Slutsky (1990) in the context of a quantity setting mixed oligopoly where firms first announce at which time they will choose their quantities and are committed to this choice before they actually choose their quantities. There are $T \geq 3$ possible periods for quantity choice and each firm may choose its quantity in only one of those $T$ periods. We consider a two stage game. In stage one, the firms simultaneously announce in which period they will choose their quantities and are committed to this choice. In stage two, after the announcement, firms then choose their quantities knowing when the other firms will make their quantity choices.

The public firm's objective is to maximize domestic social surplus defined as the sum of consumer surplus and profits of domestic firms (including itself and all domestic private firms), whereas each private firm's objective is to maximize its own profit. Thus, the objective functions of the public firm, of domestic private firm $i$ and of foreign private firm $j$ are given by

$$
\begin{aligned}
& S S= \int_{0}^{Q}(a-x-p) d x+\sum_{i=1}^{n} p q_{i}^{d}+(p-c) q_{0} \\
&= a\left(q_{0}+\sum_{i=1}^{n} q_{i}^{d}+\sum_{j=1}^{m} q_{j}^{f}\right)-\frac{1}{2}\left(q_{0}+\sum_{i=1}^{n} q_{i}^{d}+\sum_{j=1}^{m} q_{j}^{f}\right)^{2} \\
&-\left(a-q_{0}-\sum_{i=1}^{n} q_{i}^{d}-\sum_{j=1}^{m} q_{j}^{f}\right) \sum_{j=1}^{m} q_{j}^{f}-c q_{0}, \\
& \pi_{i}^{d}=p q_{i}^{d}=\left(a-q_{0}-\sum_{i=1}^{n} q_{i}^{d}-\sum_{j=1}^{m} q_{j}^{f}\right) q_{i}^{d}
\end{aligned}
$$

and

$$
\pi_{j}^{f}=p q_{j}^{f}=\left(a-q_{0}-\sum_{i=1}^{n} q_{i}^{d}-\sum_{j=1}^{m} q_{j}^{f}\right) q_{j}^{f},
$$

respectively. 
Our objective is to solve the SPNEs of this extended quantity setting mixed oligopoly game. We restrict our attention to symmetric equilibria in which all firms of the same type choose to produce in the same period. ${ }^{6}$

\section{Results for Three Periods $(T=3)$}

We derive the results for three periods $(T=3)$ in this section. The results for more than three periods are presented in Sect. 4.

In the following analysis, we let $q_{0}^{*}, Q^{*}$ and $p^{*}$ respectively denote the public firm's quantity, the total quantity and the price in equilibrium for any given timing, $q_{d}^{*}\left(q_{f}^{*}\right)$ denote a domestic (foreign) private firm's quantity for any given timing in which all domestic (foreign) private firms produce in the same period. When we consider whether a domestic or foreign private firm has incentive to deviate from any given timing, we always choose domestic private firm 1 or foreign private firm 1 to be the defector. If domestic (foreign) private firm 1 deviates, we let $q_{1}^{d^{*}}\left(q_{1}^{f^{*}}\right)$ denote the defector's quantity, $q_{i}^{d^{*}}(i=2,3, \ldots, n)\left(q_{j}^{f^{*}}(j=2,3, \ldots, m)\right)$ denote the quantity of those domestic (foreign) private firms who do not defect.

First, we prove that the public firm will not produce simultaneously with all domestic private firms. This is the following lemma.

Lemma 3.1: The public firm and all domestic private firms producing simultaneously in the same period cannot be sustained as a SPNE outcome. $^{7}$

This lemma is the same as Proposition 3.1 in Pal (1998) except that there is no foreign private firm in Pal's model. It implies that this result is robust no matter whether foreign private firms are present in the market or not.

After proving that the public firm and domestic private firms will not produce simultaneously in any equilibrium, we will show that the public firm will not act as a leader of all domestic private firms.

Lemma 3.2: The public firm acting as a leader of all domestic private firms cannot be sustained as a SPNE outcome.

6 Though we restrict our attention to symmetric equilibria, we are sure that there is no asymmetric equilibrium because no domestic (foreign) private firm wants to be a follower of the other domestic (foreign) private firms if there are at least two domestic (foreign) private firms.

7 All proofs are in the Appendix. 
By Lemma 3.1, the public firm will not produce simultaneously with all domestic private firms in any SPNE; it will not act as a leader of them either by Lemma 3.2. From these two lemmas, the following proposition follows.

Proposition 3.1: In any SPNE, the public firm acts as a follower of all domestic private firms.

Intuitively, a domestic private firm has an incentive to produce as a leader of the public firm because a domestic private firm can produce a large amount of output so that the public firm does not produce at all. Since the domestic private firms produce more efficiently than the public firm, the public firm wants to make the domestic private firms produce more by acting as a follower.

After considering the order of moves between the public firm and all domestic private firms, we will consider the order of moves between the public firm and all foreign private firms. The result is that the public firm will not be a leader of all foreign private firms. Before we give this major result, we need to prove the following claim.

Claim: The public firm chooses to produce in period 2 only when the number of the foreign private firms is at least two $(m \geq 2)$ and all domestic and foreign private firms choose to produce in period 1 .

We have proved that the public firm acts as a follower of all domestic private firms (Proposition 3.1). Given this result, the public firm produces either in period 2 or 3 . The above Claim states that the public firm chooses to produce in period 2 only when $m \geq 2$ and all domestic and foreign private firms choose to produce in period 1. In this case the public firm is a follower of all foreign private firms. And clearly the public firm is not a leader of all foreign private firms when it chooses to produce in period 3. So the second major result of this paper follows:

Proposition 3.2: The public firm acting as a leader of all foreign private firms cannot be sustained as a SPNE outcome. That is, in any SPNE, the public firm produces with all foreign private firms simultaneously or as a follower of them.

The result that the public firm chooses to produce with all foreign private firms simultaneously or as a follower of them in any SPNE is sharply different from the result in Matsumura (2003) that the public firm 
becomes the leader in the endogenous role game. So we can see that the presence of the domestic private firms has a great impact on the role of the public firm. The presence of the domestic private firms makes the public firm choose not to produce in period 1 , which in turn makes the foreign private firms choose not to be followers of the public firm.

Finally, we present the SPNEs, the number of which depends on the number of the domestic private firms and that of the foreign private firms.

Proposition 3.3: The number of SPNEs depends on the number of the domestic private firms and that of the foreign private firms. Specifically,

(1) There are 6 SPNEs when $n=1$ and $m=1$, that is, when there are only one domestic private firm and one foreign private firm in the market. In equilibrium, the public firm chooses to produce in period 3 , the domestic private firm chooses to produce in period 1 or 2 , and the foreign private firm chooses to produce in period 1,2 or 3 .

(2) There are 3 SPNEs when $n=1$ and $m \geq 2$, that is, when there are only one domestic private firm and at least two foreign private firms in the market. In any equilibrium, all foreign private firms produce in period 1. The domestic private firm and the public firm produce in period 1 and 2 , or period 1 and 3, or period 2 and 3, respectively.

(3) There are 3 SPNEs when $n \geq 2$ and $m=1$, that is, when there are at least two domestic private firms and only one foreign private firm in the market. All domestic private firms produce in period 1, the public firm produces in period 3 , and the foreign private firm produces in period 1,2 or 3.

(4) There are 2 SPNEs when $n \geq 2$ and $m \geq 2$, that is, when there are at least two domestic private firms and at least two foreign private firms in the market. All domestic and foreign private firms produce in period 1, and the public firm produces in period 2 or 3.

\section{Main Results for More than Three Periods $(T>3)$}

Proposition 4.1: If $T>3$, there are the following SPNEs:

(1) When $n=1$ and $m=1$, the public firm produces in the last period, the domestic private firm produces in any period except the last period, and the foreign private firm produces in any period; 
(2) When $n=1$ and $m \geq 2$, all foreign private firms produce in period 1, the domestic private firm produces in any period except the last period, and the public firm produces in any subsequent period after the period in which the domestic private firm produces;

(3) When $n \geq 2$ and $m=1$, all domestic private firms produce in period 1 and the public firm produces in the last period, and the foreign private firm produces in any period;

(4) When $n \geq 2$ and $m \geq 2$, all domestic and foreign private firms produce in period 1, and the public firm produces in any subsequent period.

\section{Conclusions}

In this paper, we investigate endogenous timing in a mixed oligopoly with one public firm, $n(\geq 1)$ domestic private firms and $m(\geq 1)$ foreign private firms by considering the observable delay game of Hamilton and Slutsky (1990) in the context of a quantity setting mixed oligopoly. We focus on the linear demand case. We find that the public firm chooses to be a follower of all domestic private firms, the public firm chooses not to be a leader of all foreign private firms, which is in contrast to Matsumura (2003), and that the number of subgame perfect Nash equilibria depends on the number of the domestic private firms and that of the foreign private firms.

The results in this paper question the exogenous timing in the research of a mixed oligopoly with both domestic and foreign private firms. If the firms could choose the timing of their quantity choices, the timing should be endogenous. The contribution of this paper is to extend Pal (1998) by introducing foreign private firms into a mixed oligopoly. Also a mixed oligopoly consisting of public firm, domestic and foreign private firms is more realistic.

A limitation of the paper is that we consider the linear demand case only. As we can see, there exist many equilibria in this case. Whether all these equilibria survive under nonlinear demand function needs to be explored. This is a direction for future research. A good reference is Matsumura (2003) in which the author used a general demand function with the property of $p^{\prime \prime} \leq 0$ and showed that the public firm acts as a leader in a mixed duopoly with a foreign competitor. 
One extension of this paper could consider the efficiency differential between the domestic private firms and foreign private firms. Generally, foreign ones are more efficient. So we could assume foreign private firms' marginal costs are zero, while domestic ones' marginal costs are positive but less than public firms'. This is also left for future research.

\section{Appendix}

If all firms produce simultaneously in period $t(=1,2,3)$, then every firm's payoff maximization problems give us the following first-order conditions:

$$
\begin{aligned}
\frac{\partial S S}{\partial q_{0}} & =a-\left(q_{0}+\sum_{i=1}^{n} q_{i}^{d}+\sum_{j=1}^{m} q_{j}^{f}\right)+\sum_{j=1}^{m} q_{j}^{f}-c \\
& =a-\left(q_{0}+\sum_{i=1}^{n} q_{i}^{d}\right)-c=0 \\
\frac{\partial \pi_{i}^{d}}{\partial q_{i}^{d}} & =a-q_{0}-\sum_{k=1, k \neq i}^{n} q_{k}^{d}-\sum_{j=1}^{m} q_{j}^{f}-2 q_{i}^{d}=0, \text { for } i=1,2, \ldots, n, \\
\frac{\partial \pi_{j}^{f}}{\partial q_{j}^{f}} & =a-q_{0}-\sum_{i=1}^{n} q_{i}^{d}-\sum_{l=1, l \neq j}^{m} q_{l}^{f}-2 q_{j}^{f}=0, \text { for } j=1,2, \ldots, m .
\end{aligned}
$$

\section{Proof of Lemma 1}

We can show that either the public firm or a domestic private firm has incentive to deviate if the public firm and all domestic private firms produce simultaneously in the same period, that is, deviate from the following three cases. ${ }^{8}$

8 We provide a table (Table 1) to list one example of profitable defection for every case (and subcase) which cannot be sustained as SPNE. 
Table 1. Profitable defection in every case and SPNE

\begin{tabular}{llllll}
\hline No. & Period 1 & Period 2 & Period 3 & $\begin{array}{l}\text { Example of } \\
\text { Profitable Defection }\end{array}$ & $\begin{array}{l}\text { Ruled out } \\
\text { or SPNE }\end{array}$ \\
\hline 1 & $\mathrm{p}, \mathrm{d}$ & $\mathrm{f}$ & $\begin{array}{l}\mathrm{p} \text { deviates to produce } \\
\text { simultaneously with f }\end{array}$ & $\begin{array}{l}\text { Ruled out by } \\
\text { Lemma 1 } \\
\text { (Case 1.1) }\end{array}$ \\
\hline
\end{tabular}

\begin{tabular}{llll}
\hline 2 & $\mathrm{p}, \mathrm{d}$ & & $\mathrm{f}$ \\
3 & & $\mathrm{p}, \mathrm{d}$ & $\mathrm{f}$ \\
\hline 4 & $\mathrm{f}$ & $\mathrm{p}, \mathrm{d}$
\end{tabular}

$\begin{array}{llll}5 & \mathrm{f} & \mathrm{p}, \mathrm{d} \\ 6 & & \mathrm{f} & \mathrm{p}, \mathrm{d}\end{array}$

$\mathrm{d}_{1}$ deviates to produce Ruled out by simultaneously with $\mathrm{f}$ Lemma 1

(Case 1.2)

\begin{tabular}{lll}
\hline $7 \mathrm{p}, \mathrm{d}, \mathrm{f}$ & $\begin{array}{c}\mathrm{p} \text { deviates to produce } \\
\text { as a follower }\end{array}$ & $\begin{array}{c}\text { Ruled out by } \\
\text { Lemma } 1\end{array}$ \\
& & (subcase 1.3.1)
\end{tabular}

$8 \quad \mathrm{p}, \mathrm{d}, \mathrm{f}$

$9 \quad \mathrm{p}, \mathrm{d}, \mathrm{f} \quad \mathrm{d}_{1}$ deviates to produce Ruled out by as a leader Lemma 1

(subcase 1.3.2)

\begin{tabular}{cccc}
$10 \mathrm{p}$ & $\mathrm{d}, \mathrm{f}$ & $\begin{array}{c}\mathrm{p} \text { deviates to produce } \\
\text { in period } 3\end{array}$ & $\begin{array}{c}\text { Ruled out by } \\
\text { Lemma } 2 \\
\text { (subcase 2.1.1) }\end{array}$ \\
\hline
\end{tabular}

\begin{tabular}{llll}
\hline $11 \mathrm{p}$ & $\mathrm{d}, \mathrm{f}$ & $\begin{array}{c}\mathrm{d}_{1} \text { deviates to produce } \\
\text { in period } 2\end{array}$ & $\begin{array}{l}\text { Ruled out by } \\
\text { Lemma } 2 \\
\text { (subcase 2.1.2) }\end{array}$ \\
\hline
\end{tabular}

\begin{tabular}{|c|c|c|c|c|c|}
\hline 12 & & $\mathrm{p}$ & $\mathrm{d}, \mathrm{f}$ & $\begin{array}{l}\mathrm{d}_{1} \text { deviates to produce } \\
\text { in period } 1\end{array}$ & $\begin{array}{l}\text { Ruled out by } \\
\text { Lemma } 2 \\
\text { (subcase } 2.1 .3 \text { ) }\end{array}$ \\
\hline 13 & $\mathrm{p}, \mathrm{f}$ & $\mathrm{d}$ & & $\begin{array}{l}\mathrm{p} \text { deviates to produce } \\
\text { in period } 3\end{array}$ & $\begin{array}{l}\text { Ruled out by } \\
\text { Lemma } 2 \\
\text { (subcase } 2.2 .1 \text { ) }\end{array}$ \\
\hline 14 & $\mathrm{p}, \mathrm{f}$ & & $d$ & $\begin{array}{l}\mathrm{f}_{1} \text { deviates to produce } \\
\text { in period } 2\end{array}$ & $\begin{array}{l}\text { Ruled out by } \\
\text { Lemma } 2 \\
\text { (subcase } 2.2 .2 \text { ) }\end{array}$ \\
\hline 15 & & $\mathrm{p}, \mathrm{f}$ & $d$ & $\begin{array}{l}\mathrm{d}_{1} \text { deviates to produce } \\
\text { in period } 1\end{array}$ & $\begin{array}{l}\text { Ruled out by } \\
\text { Lemma } 2 \\
\text { (subcase } 2.2 .3 \text { ) }\end{array}$ \\
\hline 16 & $\mathrm{p}$ & $\mathrm{d}$ & $\mathrm{f}$ & $\begin{array}{l}\mathrm{p} \text { deviates to produce } \\
\text { in period } 2\end{array}$ & $\begin{array}{l}\text { Ruled out by } \\
\text { Lemma } 2 \\
\text { (Case } 2.3 \text { ) }\end{array}$ \\
\hline
\end{tabular}


Table 1. (continued)

\begin{tabular}{|c|c|c|c|c|c|}
\hline No. & Period 1 & Period 2 & Period 3 & $\begin{array}{l}\text { Example of } \\
\text { Profitable Defection }\end{array}$ & $\begin{array}{l}\text { Ruled out } \\
\text { or SPNE }\end{array}$ \\
\hline 17 & $\mathrm{p}$ & $\mathrm{f}$ & d & $\begin{array}{l}\mathrm{d}_{1} \text { deviates to produce } \\
\text { in period } 1\end{array}$ & $\begin{array}{l}\text { Ruled out by } \\
\text { Lemma } 2 \\
\text { (Case } 2.4)\end{array}$ \\
\hline 18 & $\mathrm{f}$ & $\mathrm{p}$ & d & $\begin{array}{l}\mathrm{d}_{1} \text { deviates to produce } \\
\text { in period } 1\end{array}$ & $\begin{array}{l}\text { Ruled out by } \\
\text { Lemma } 2 \\
\text { (Case } 2.5)\end{array}$ \\
\hline 19 & $\mathrm{~d}, \mathrm{f}$ & $\mathrm{p}$ & & $\begin{array}{l}\mathrm{f}_{1} \text { deviates to produce } \\
\text { in period } 3 \text { when } m=1\end{array}$ & $\begin{array}{l}\text { Ruled out by } \\
\text { Lemma } 2 \\
\text { when } m=1 \text {; } \\
\text { SPNE when } \\
m \geq 2 \\
\text { (Case } 3.1)\end{array}$ \\
\hline 20 & d & $\mathrm{p}, \mathrm{f}$ & & $\begin{array}{l}\mathrm{f}_{1} \text { deviates to produce } \\
\text { in period } 3\end{array}$ & $\begin{array}{l}\text { Ruled out by } \\
\text { Claim } \\
\text { (Case } 3.2 \text { ) }\end{array}$ \\
\hline 21 & d & $\mathrm{p}$ & $\mathrm{f}$ & $\begin{array}{l}\mathrm{p} \text { deviates to produce } \\
\text { in period } 3\end{array}$ & $\begin{array}{l}\text { Ruled out by } \\
\text { Claim } \\
\text { (Case } 3.3 \text { ) }\end{array}$ \\
\hline 22 & $\mathrm{~d}, \mathrm{f}$ & & $\mathrm{p}$ & & SPNE \\
\hline 23 & d & $\mathrm{f}$ & $\mathrm{p}$ & $\begin{array}{l}\mathrm{f}_{1} \text { deviates to produce } \\
\text { in period } 1 \text { when } m \geq 2\end{array}$ & $\begin{array}{l}\text { SPNE when } \\
m=1\end{array}$ \\
\hline 24 & $\mathrm{~d}$ & & $f, p$ & $\begin{array}{l}\mathrm{f}_{1} \text { deviates to produce in } \\
\text { period } 1 \text { (or } 2 \text { ) when } m \geq 2\end{array}$ & $\begin{array}{l}\text { SPNE when } \\
m=1\end{array}$ \\
\hline 25 & $\mathrm{f}$ & d & $\mathrm{p}$ & $\begin{array}{l}\mathrm{d}_{1} \text { deviates to produce in } \\
\text { period } 1 \text { when } n \geq 2\end{array}$ & $\begin{array}{l}\text { SPNE when } \\
n=1\end{array}$ \\
\hline 26 & & $f, d$ & $\mathrm{p}$ & $\begin{array}{l}\mathrm{d}_{1} \text { deviates to produce } \\
\text { in period } 1 \text { when } \\
n \geq 2, \mathrm{f}_{1} \text { deviates } \\
\text { to produce in period } 1 \\
\text { when } m \geq 2\end{array}$ & $\begin{array}{c}\text { SPNE when } \\
n=m=1\end{array}$ \\
\hline 27 & & d & $f, p$ & $\begin{array}{l}\mathrm{d}_{1} \text { deviates to produce in } \\
\text { period } 1 \\
\text { when } n \geq 2, \mathrm{f}_{1} \text { deviates } \\
\text { to produce } \\
\text { in period } 1 \text { (or } 2 \text { ) when } \\
m \geq 2\end{array}$ & $\begin{array}{l}\text { SPNE when } \\
n=m=1\end{array}$ \\
\hline
\end{tabular}

Note: In columns 2, 3, 4 and $5, \mathrm{p}, \mathrm{d}$, f denote the public firm, domestic private firms and foreign private firms. In column $5, \mathrm{~d}_{1}$ and $\mathrm{f}_{1}$ denote domestic private firm 1 and foreign private firm 1 , respectively. 
Case 1.1: The public firm and all domestic private firms produce simultaneously as leaders and all foreign private firms produce simultaneously as followers.

If this is the case, then from (A.3), we can obtain foreign private firm $j$ 's reaction function, $q_{j}^{f}=\left(a-q_{0}-\sum_{i=1}^{n} q_{i}^{d}-\sum_{l=1, l \neq j}^{m} q_{l}^{f}\right) / 2$, and thus $q_{j}^{f}=\left(a-q_{0}-\sum_{i=1}^{n} q_{i}^{d}\right) /(m+1)$. It follows that $Q=\left(m a+q_{0}+\right.$ $\left.\sum_{i=1}^{n} q_{i}^{d}\right) /(m+1)$ and $p=\left(a-q_{0}-\sum_{i=1}^{n} q_{i}^{d}\right) /(m+1)$. Thus, the public firm's objective function becomes

$$
\begin{aligned}
S S= & a\left(m a+q_{0}+\sum_{i=1}^{n} q_{i}^{d}\right) /(m+1)-\frac{1}{2}\left(m a+q_{0}+\sum_{i=1}^{n} q_{i}^{d}\right)^{2} /(m+1)^{2} \\
& -m\left(a-q_{0}-\sum_{i=1}^{n} q_{i}^{d}\right)^{2} /(m+1)^{2}-c q_{0},
\end{aligned}
$$

and a domestic private firm $i$ 's profit function becomes $\pi_{i}^{d}=\left(a-q_{0}-\sum_{i=1}^{n} q_{i}^{d}\right) q_{i}^{d} /(m+1)$. We can obtain the following firstorder conditions:

$$
\begin{gathered}
\frac{\partial S S}{\partial q_{0}}=(2 m+1)\left(a-q_{0}-\sum_{i=1}^{n} q_{i}^{d}\right) /(m+1)^{2}-c=0, \\
\frac{\partial \pi_{i}^{d}}{\partial q_{i}^{d}}=a-q_{0}-\sum_{k=1, k \neq i}^{n} q_{k}^{d}-2 q_{i}^{d}=0, \quad \text { for } i=1,2, \ldots, n .
\end{gathered}
$$

Solving these equations yields $q_{0}^{*}=a-(n+1)(m+1)^{2} c /(2 m+1)$, $q_{d}^{*}=(m+1)^{2} c /(2 m+1), q_{f}^{*}=(m+1) c /(2 m+1), Q^{*}=a-(m+1)$ $c /(2 m+1)$ and $p^{*}=(m+1) c /(2 m+1)$.

Now consider the case in which the public firm deviates to produce simultaneously with all foreign private firms instead. Then from (A.1) and (A.3), we can obtain $q_{f}^{*}=c /(m+1)$ and the public firm's reaction function, $q_{0}=a-\sum_{i=1}^{n} q_{i}^{d}-c$. It follows that $p *=c /(m+1)$ and $Q^{*}=a-c /(m+1)$. As leaders of the public firm, all domestic private firms produce as more as possible such that $q_{0}^{*}=0$ and the total equilibrium output of the domestic private firms is $a-c$.

Comparing this deviation case with Case 1.1, we find that the total output is larger, the equilibrium price is lower, the output of a foreign private firm is smaller, and more output is now being produced by more 
efficient domestic private firms. So the public firm has incentive to deviate from Case 1.1.

Case 1.2: All foreign private firms produce simultaneously as leaders and the public firm and all domestic private firms produce simultaneously as followers.

If this is the case, then from (A.1) and (A.2), we can obtain domestic private firm $i$ 's reaction function, $q_{i}^{d}=\left(a-q_{0}-\sum_{k=1, k \neq i}^{n} q_{k}^{d}-\right.$ $\left.\sum_{j=1}^{m} q_{j}^{f}\right) / 2$ and the public firm's reaction function, $q_{0}=a-c-\sum_{i=1}^{n} q_{i}^{d}$. It follows that $q_{i}^{d}=c-\sum_{j=1}^{m} q_{j}^{f}, q_{0}=a-(n+1) c+n \sum_{j=1}^{m} q_{j}^{f}$, and $p=c-\sum_{j=1}^{m} q_{j}^{f}$. Thus, foreign private firm $j$ 's profit function becomes $\pi_{j}^{f}=\left(c-\sum_{j=1}^{m} q_{j}^{f}\right) q_{j}^{f}$. We can easily get a foreign private firm's profitmaximization output, $q_{f}^{*}=c /(m+1)$. It follows that $q_{0}^{*}=a-c-n c /$ $(m+1), q_{d}^{*}=c /(m+1), Q^{*}=a-c /(m+1)$ and $p^{*}=c /(m+1)$.

Now consider the case in which domestic private firm 1 deviates to produce simultaneously with all foreign private firms as a leader. Then we can obtain domestic private firm $i$ 's reaction function, $q_{i}^{d}=\left(a-q_{0}-q_{1}^{d}-\sum_{k=2, k \neq i}^{n} q_{k}^{d}-\sum_{j=1}^{m} q_{j}^{f}\right) / 2(i=2,3, \ldots, n)$ and the public firm's reaction function, $q_{0}=a-c-\sum_{i=1}^{n} q_{i}^{d}$. It follows that $q_{i}^{d}=c-\sum_{j=1}^{m} q_{j}^{f}(i=2,3, \ldots n), q_{0}=a-q_{1}^{d}-n c+(n-1) \sum_{j=1}^{m} q_{j}^{f}$ and $p=c-\sum_{j=1}^{m} q_{j}^{f}$. Thus, foreign private firm j's and domestic private firm 1's profit function become $\pi_{j}^{f}=\left(c-\sum_{j=1}^{m} q_{j}^{f}\right) q_{j}^{f}$ and $\pi_{1}^{d}=\left(c-\sum_{j=1}^{m} q_{j}^{f}\right) q_{1}^{d}$, respectively. We can easily get a foreign private firm's and domestic private firm 1's profit-maximization output, $q_{f}^{*}=c /(m+1)$ and $q_{1}^{d^{*}}=a-(n+m) c /(m+1)$. It follows that $p^{*}=c /(m+1)$. Clearly, domestic private firm 1 now produces more while the price does not change and thus it has incentive to deviate from Case 1.2.

Case 1.3: All the firms produce simultaneously.

If this is the case, then solving (A.1), (A.2) and (A.3), we get the equilibrium outcome: $q_{0}^{*}=a-c-n c /(m+1), q_{d}^{*}=q_{f}^{*}=c /(m+1)$. It follows that $Q^{*}=a-c /(m+1)$ and $p^{*}=c /(m+1)$.

There are two subcases to consider.

Subcase 1.3.1: All firms produce simultaneously in period $t(=1$ or 2$)$.

Consider the public firm deviates to be a follower, then the public firm's reaction function is $q_{0}=a-\sum_{i=1}^{n} q_{i}^{d}-c$ and thus 
$p=c-\sum_{j=1}^{m} q_{j}^{f}$. In period $t(=1$ or 2$)$, all domestic firms want to produce as more as possible since price is positive and is independent of their output provided that the total output is not too large. Thus, $\sum_{i=1}^{n} q_{i}^{d}=a-c$ such that $q_{0}=0$. All foreign private firms' profit function becomes $\pi_{j}^{f}=\left(c-\sum_{j=1}^{m} q_{j}^{f}\right) q_{j}^{f}$ and their equilibrium output is $q_{f}^{*}=c /(m+1)$. Hence, the equilibrium outcome is that $q_{0}^{*}=0$, the total equilibrium output of the domestic private firms is $a-c, q_{f}^{*}=c /(m+1), Q^{*}=a-c /(m+1)$ and $p^{*}=c /(m+1)$.Comparing this deviation case with subcase 1.3.1, we find that the total output, the equilibrium price and the output of a foreign private firm do not change, but more output is now being produced by more efficient domestic private firms. So the public firm has incentive to deviate from subcase 1.3.1.

Subcase 1.3.2: All firms produce simultaneously in period 3.

Consider domestic private firm 1 deviates to be a leader in period $t(=1$ or 2$)$, then we can find that in period $3 q_{f}^{*}=q_{i}^{d^{*}}=c /(m+1)$, for $i=2, \ldots, n$ and $q_{0}=a-(n+m) c /(m+1)-q_{1}^{d}$. It follows that $p *=c /(m+1)$. In period $t(=1$ or 2$)$, domestic private firm 1 wants to produce as more as possible such that $q_{0}=0$. Thus, $q_{1}^{d^{*}}=a-(n+m) c /(m+1)$. Comparing this deviation case with subcase 1.3.2, we find that the equilibrium price does not change and domestic private firm 1 now produces more, so it has incentive to deviate from subcase 1.3.2.

\section{Proof of Lemma 2}

We can show that either the public firm, or a domestic private firm, or a foreign private firm has incentive to deviate from the cases in which the public firm acts as a leader of all domestic private firms. There are five cases to consider.

Case 2.1: The public firm produces as a leader, and all domestic and foreign private firms produce simultaneously as followers.

Case 2.2: The public firm and all foreign private firms produce as a leader, and all domestic private firms produce simultaneously as followers.

Case 2.3: The public firm, all domestic private firms and the foreign private firms produce in period 1,2 , and 3 , respectively. 
Case 2.4: The public firm, all foreign private firms and the domestic private firms produce in period 1,2 , and 3 , respectively.

Case 2.5: All foreign private firms, the public firm and the domestic private firms and produce in period 1,2 , and 3 , respectively.

Now we prove Case 2.1 cannot be sustained as SPNE. There are three subcases to consider.

In Case 2.1, the equilibrium outcome is $q_{0}^{*}=a-(n+m+1)^{2} c /$ $(2 m+1), q_{d}^{*}=q_{f}^{*}=(n+m+1) c /(2 m+1), Q^{*}=a-(n+m+1) c /$ $(2 m+1)$ and $p^{*}=(n+m+1) c /(2 m+1)$.

Subcase 2.1.1: The public firm acts as a leader in period 1 and all domestic and foreign private firms produce simultaneously as followers in period 2.

If the public firm produces in period 3 instead, then the equilibrium outcome is $q_{0}^{*}=0$, the total equilibrium output of the domestic private firms is $\quad a-c, q_{f}^{*}=c /(m+1), Q^{*}=a-c /(m+1) \quad$ and $p^{*}=c /(m+1)$. Comparing this deviation case with subcase 2.1.1, we find that the total output is larger, the equilibrium price is lower, the output of a foreign private firm is smaller, and more output is now being produced by more efficient domestic private firms. So the public firm has incentive to deviate from Case 2.1.1.

Subcase 2.1.2: The public firm acts as a leader in period 1, and all domestic and foreign private firms produce simultaneously as followers in period 3.

If domestic private firm 1 produces in period 2 instead, then the equilibrium outcome is $q_{0}^{*}=a-4(n+m)^{2} c /(2 m+1), q_{1}^{d^{*}}=2(n+m)^{2}$ $c /(2 m+1), q_{i}^{d^{*}}=q_{f}^{*}=2(n+m) c /(2 m+1)(i=2,3, \ldots, n), \quad Q^{*}=$ $a-2(n+m) c /(2 m+1)$ and $p^{*}=2(n+m) c /(2 m+1)$. Comparing this deviation case with subcase 2.1.2, we find that the equilibrium price is higher and domestic private firm 1 now produces more, so it has incentive to deviate from subcase 2.1.2.

Subcase 2.1.3: The public firm acts as a leader in period 2 and all domestic and foreign private firms produce simultaneously as followers in period 3 .

If domestic private firm 1 produces in period 1 instead, then the equilibrium outcome is $q_{0}^{*}=0, q_{1}^{d^{*}}=a-(n+m)^{2} c /(2 m+1), q_{i}^{d^{*}}=$ 
$q_{f}^{*}=(n+m) c /(2 m+1)(i=2,3, \ldots, n), Q^{*}=a-(n+m) c /(2 m+1)$ and $p^{*}=(n+m) c /(2 m+1)$. Comparing this deviation case with subcase 2.1.3, we find that domestic private firm 1's profit increases, so it has incentive to deviate from subcase 2.1.3.

Similarly, we can prove all the other cases mentioned above cannot be sustained as SPNE by showing that either the public firm, or a domestic private firm, or a foreign private firm has incentive to deviate. We list one example of profitable defection in each case in Table 1. Note that Case 2.2 includes three subcases:

Subcase 2.2.1: The public firm and all foreign private firms act as leaders in period 1, and domestic private firms produce simultaneously as followers in period 2 .

Subcase 2.2.2: The public firm and all foreign private firms act as leaders in period 1 , and domestic private firms produce simultaneously as followers in period 3 .

Subcase 2.2.3: The public firm and all foreign private firms act as leaders in period 2, and domestic private firms produce simultaneously as followers in period 3 .

\section{Proof of Claim}

We have proved that the public firm acts as a follower of all domestic private firms (Proposition 3.1). Given this result, if the public firm produces in period 2, all domestic private firms must produce in period 1 , and thus there are only the following three cases to consider.

Case 3.1: All foreign private firms produce in period 1.

In this case, the equilibrium outcome is that $q_{0}^{*}=0$, the total equilibrium output of the domestic private firms is $a-c, q_{f}^{*}=c /(m+1)$, $Q^{*}=a-c /(m+1)$ and $p^{*}=c /(m+1)$. Clearly, the public firm has no incentive to deviate to produce in period 3 and proof of Lemma 3.1 (subcase 1.3.1) shows it will not deviate to produce in period 1 . We can also show that a domestic private firm has no incentive to deviate; this can be easily understood since it is already a leader of the public firm in Case 3.1. Next we consider whether a foreign private firm, say foreign private firm 1 , has incentive to deviate. 
If foreign private firm 1 deviates to produce in period 3 , we can show that $p^{*}=q_{1}^{f *}=2 c / 3 m$ and thus $\pi_{1}^{f}=4 c^{2} /\left(9 m^{2}\right)$. If it does not deviate, $\pi_{1}^{f}=c^{2} /(m+1)^{2}$. Clearly, it has incentive to deviate when $m=1$ and has no incentive when $m \geq 2$.

If foreign private firm 1 deviates to produce in period 2, we can show that $p^{*}=q_{1}^{f *}=c / 2 m$ and thus $\pi_{1}^{f}=c^{2} / 4 m^{2}$. If it does not deviate, $\pi_{1}^{f}=c^{2} /(m+1)^{2}$. Clearly, it has no incentive to deviate.

So Case 3.1 can be sustained as SPNE when $m \geq 2$ and cannot when $m=1$.

Case 3.2: All foreign private firms produce in period 2.

In this case, $p^{*}=q_{f}^{*}=c /(m+1)$ and thus $\pi_{1}^{f}=c^{2} /(m+1)^{2}$. If foreign private firm 1 deviates to produce in period 3 , then we can show that in equilibrium $p^{*}=q_{1}^{f^{*}}=2 c /(2 m+1)$ and thus $\pi_{1}^{f}=4 c^{2} /(2 m+1)^{2}$, which is greater than $c^{2} /(m+1)^{2}$. So it has incentive to deviate.

Case 3.3: All foreign private firms produce in period 3.

In this case, the equilibrium outcome is that $q_{0}^{*}=0$, the total equilibrium output of the domestic private firms is $a-(m+1)^{2} c /(2 m+1)$, $q_{f}^{*}=(m+1) c /(2 m+1), Q^{*}=a-(m+1) c /(2 m+1)$ and $p^{*}=(m+1)$ $c /(2 m+1)$. If the public firm deviates to produce in period 3 , then $q_{0}^{*}=0$, the total equilibrium output of the domestic private firms is $a-c, q_{f}^{*}=c /(m+1), Q^{*}=a-c /(m+1)$ and $p^{*}=c /(m+1)$. Comparing this deviation case with Case 3.3, we find that the total output is larger, the equilibrium price is lower, the output of a foreign private firm is smaller, and more output is now being produced by more efficient domestic private firms. So the public firm has incentive to deviate from Case 3.3.

\section{Proof of Proposition 3.3}

We prove this proposition by checking that no firm has incentive to deviate in each SPNE of each case.

(1) When $n=1$ and $m=1$ : Firstly, note that the public firm chooses to produce in period 3 when $m=1$ (which follows from Claim). Secondly, the domestic private firm has no incentive to deviate since it is a leader of the public firm and cannot increase its output because there is only one domestic private firm. Thirdly, the first order condition of the public firm's domestic social welfare maximization problem is $\partial S S / \partial q_{0}=a-\left(q_{0}+q_{1}^{d}\right)-c=0$, that is, 


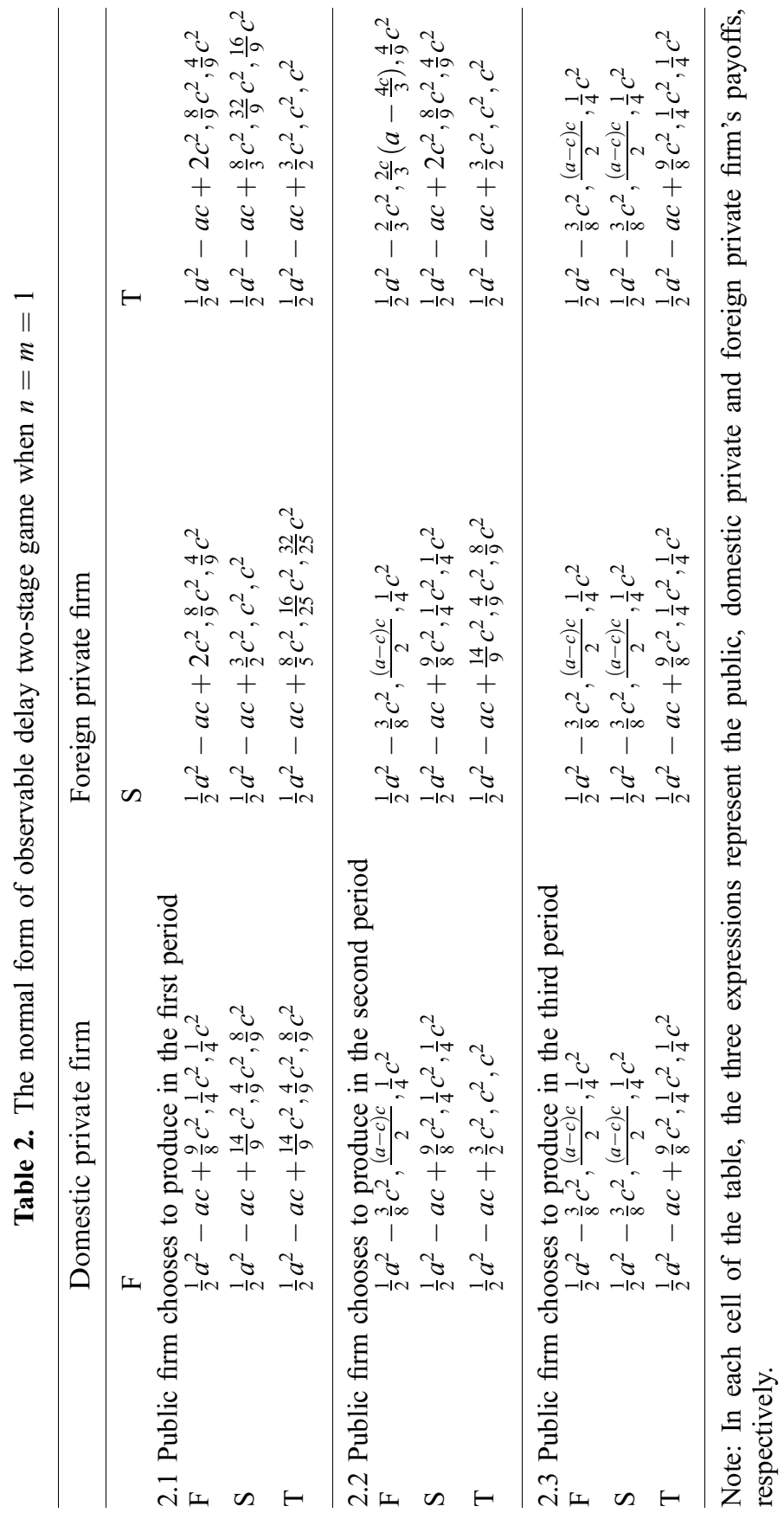


$p=c-q_{1}^{f}$. If the foreign private firm produces in period 1 or 2 , then its profit-maximization output is $q_{1}^{f *}=\frac{c}{2}$. Meanwhile, when the foreign private firm produces in period 3 , the first-order condition of its profit maximizing problem is $\partial \pi_{1}^{f} / \partial q_{1}^{f}=a$ $-\left(q_{0}+q_{1}^{d}\right)-2 q_{1}^{f}=0$ (and the first-order condition of the public firm's welfare maximizing problem is $\partial S S / \partial q_{0}=a$ $\left.-\left(q_{0}+q_{1}^{d}\right)-c=0\right)$ and its profit-maximizing output is the same. Hence, the foreign private firm does not care about in which period to produce. To make it clearer, the normal form of observable delay two-stage game when $n=m=1$ is provided in Table 2 .

(2) When $n=1$ and $m \geq 2$ : Firstly, the public firm has no incentive to deviate. Secondly, the domestic private firm has no incentive to deviate for the same reason as in the first case. Thirdly, no foreign private firm has incentive to deviate because the domestic private firm's output will increase while its output will decrease if it deviates.

(3) When $n \geq 2$ and $m=1$ : Firstly, the public firm has no incentive to deviate. Secondly, all domestic private firms have no incentive to deviate since they want to produce more in period 1 and cannot increase its output by deviating. Thirdly, the only foreign private firm has no incentive to deviate for the same reason as in the first case.

(4) When $n \geq 2$ and $m \geq 2$ : Firstly, the public firm has no incentive to deviate. Secondly, all domestic and foreign private firms have no incentive to deviate since they want to produce more in period 1 and cannot increase its output by deviating.

\section{Proof of Proposition 4.1}

We need to note that a foreign private firm has incentive to deviate to be a follower of the public firm if $m=1$. So the public firm must produce in the last period when $m=1$. We also need to note that a domestic (foreign) private firm has incentive to produce in period 1 if there are at least two domestic (foreign) private firms. Therefore, all domestic (foreign) private firms must produce in period 1 if $n \geq 2(m \geq 2)$.

\section{Acknowledgements}

I am grateful to John Wooders, three anonymous referees, and Giacomo Corneo (the managing editor) for their valuable comments on earlier versions of this paper. All errors are mine. 


\section{References}

Bárcena-Ruiz, J. C., and Garzón, M. B. (2003): "Mixed Duopoly, Merger and Multiproduct Firms." Journal of Economics 80: 27-42.

Corneo, G., and Jeanne, O. (1994): "Oligopole Mixte dans un Marché Commun." Annales d'Economie et de Statistique 33: 73-90.

De Fraja, G., and Delbono, F. (1990): "Game Theoretic Models of Mixed Oligopoly." Journal of Economic Surveys 4: 1-17.

Fjell, K., and Pal, D. (1996): "A Mixed Oligopoly in the Presence of Foreign Private Firms." Canadian Journal of Economics 29: 737-743.

Fjell, K., and Heywood, J. S. (2002): "Public Stackelberg Leadership in a Mixed Oligopoly with Foreign Firms.” Australian Economic Papers 41: 267-281.

Fjell, K., and Heywood, J. S. (2004): "Mixed Oligopoly, Subsidization and the Order of Firm's Moves: the Relevance of Privatization." Economics Letters 83: 411-416.

Hamilton, J., and Slutsky, S. (1990): "Endogenous Timing in Duopoly Games: Stackelberg or Cournot Equilibria." Games and Economic Behavior 2: 29-46.

Jacques, A. (2004): "Endogenous Timing in a Mixed Oligopoly: a Forgotten Equilibrium" Economics Letters 83: 147-148.

Lu, Y., and Poddar, S. (2005): "The Choice of Capacity in Mixed Duopoly under Demand Uncertainty." The Manchester School (forthcoming).

Matsumura, T. (2003): "Stackelberg Mixed Duopoly with a Foreign Competitor." Bulletin of Economic Research 55: 275-287.

Matsumura, T., and Kanda, O. (2005): "Mixed Oligopoly at Free Entry Markets." Journal of Economics 84: 27-48.

Matsushima, N., and Matsumura, T. (2003a): "Mixed Duopoly with Product Differentiation: Sequential Choice of Location." Australian Economic Papers 42: $18-34$.

Matsushima, N., and Matsumura, T. (2003b): "Mixed Oligopoly and Spatial Agglomeration." Canadian Journal of Economics 36: 62-87.

Matsushima, N., and Matsumura, T. (2005): "Mixed Oligopoly, Foreign Firms, and Location Choice." Discussion Paper 2005-21, Graduate School of Business Administration, Kobe University.

Nett, L. (1993): "Mixed Oligopoly with Homogenous Goods.” Annals of Public and Cooperative Economics 64: 367-394.

Pal, D. (1998): "Endogenous Timing in a Mixed Oligopoly." Economics Letters 61: 181-185.

Addresses of author: - Yuanzhu Lu, Department of Economics, Faculty of Arts and Social Sciences, National University of Singapore, AS2 Level 6, 1 Arts Link, Singapore 117570 (e-mail: yuanzhulu@nus.edu.sg) and China Economics and Management Academy, Central University of Finance and Economics, No. 39 College South Road, Beijing, China, 100081 